OPEN ACCESS

Edited by:

Su Shiung Lam,

Universiti Malaysia

Terengganu, Malaysia

Reviewed by:

Fehmi Akgun

Tubitak Marmara Research Centre

Energy Institute, Turkey

Azlina Karim

Putra Malaysia University, Malaysia

*Correspondence: Javier Bonilla

jbonillap@ecci.edu.co

Specialty section:

This article was submitted to

Bioenergy and Biofuels,

a section of the journal

Frontiers in Energy Research

Received: 17 July 2019

Accepted: 29 October 2019

Published: 26 November 2019

Citation:

Bonilla J, Gordillo G and Cantor C (2019) Experimental Gasification of Coffee Husk Using Pure Oxygen-Steam Blends.

Front. Energy Res. 7:127.

doi: 10.3389/fenrg.2019.00127

\section{Experimental Gasification of Coffee Husk Using Pure Oxygen-Steam Blends}

\author{
Javier Bonilla ${ }^{1 *}$, Gerardo Gordillo ${ }^{2}$ and Carlos Cantor $^{3}$ \\ ${ }^{1}$ Grupo de Investigación de Aprovechamiento Tecnológico de Materiales y Energía, Universidad ECCl, Bogota, Colombia, \\ ${ }^{2}$ Research Group of Energy Conversion, Department of Mechanical Engineering, Universidad de los Andes, Bogota, \\ Colombia, ${ }^{3}$ Department of Mechanical Engineering, School of Basic Sciences, Technology and Engineering, Universidad \\ Nacional Abierta y a Distancia, Bogota, Colombia
}

This work discusses results on temperature profile, syngas composition, High Heating Value, and efficiency of a Coffee Husk counter-current fixed-bed gasification process, in which oxygen-steam blends were used as an oxidizing agent. The experimentation was carried out for various Equivalence Ratios (ER) and Steam-Fuel Ratios (SF), whose ranges were [1.6-5.6] and [0.4-0.8], respectively. The results show that increased steam (higher steam fuel ratios) improves the $\mathrm{H}_{2} / \mathrm{CO}$ molar ratio i.e., for a constant $\mathrm{ER}=3.7$ and SF at $0.4,0.6$, and 0.8 , the $\mathrm{H}_{2} / \mathrm{CO}$ ratio was $1.2,1.4$, and 1.8 , respectively. Also, the addition of steam tends to increase the syngas Higher Heating Value, which ranged between $7,714 \mathrm{~kJ} / \mathrm{m}^{3}$ at $\mathrm{ER}=1.6$ and $\mathrm{SF}=0.4$ and $8,841 \mathrm{~kJ} / \mathrm{m}^{3}$ at $\mathrm{ER}=3.2$ and $\mathrm{SF}=$ 0.8. On the other hand, increased ER (lower oxygen) decreases the Net Cold Gasification Efficiency (CGENET) which was between $53 \%$ at $\mathrm{ER}=5.6$ and $\mathrm{SF}=0.6$ and $82 \%$ at $\mathrm{ER}=$ 1.6 and $\mathrm{SF}=0.4$. Results were also compared to results published before for gasification of the same biomass but using air-steam mixtures for partial oxidation. This comparison shows that the use of oxygen increases both the temperature profile in the bed and the yield of $\mathrm{CO}$ and $\mathrm{H}_{2}$ contained in the syngas.

Keywords: biomass gasification, coffee husk, updraft gasifier, oxygen gasifying agent, syngas

\section{HIGHLIGHTS}

- Use of coffee husk as agro-industrial waste for generation of fuel.

- Quality enhancement of syngas by yielding oxygen-steam agents into the gasifier.

- Small-scale gasification technology very appropriate to generate syngas to low cost for many farms.

\section{INTRODUCTION}

The continuous increase in both energy consumption and emissions, generated in the combustion of fossil fuels, around the world (International Energy Agency, 2016) has stimulated the study of new sustainable energy technologies to reduce the dependence of the population on fossil fuels. The economies of many countries are based on agro-industry, a sector that produces a lot of biomass residues that can be used as feedstock for the production of solid, liquid, and gas biofuels via 
thermochemical or biological gasification processes (Abbasi and Abbasi, 2010; Gírio et al., 2010; Yang et al., 2014; Aslan, 2016; Chen, 2016; Cutz et al., 2016; Joselin Herbert and Unni Krishnan, 2016; Bilgili et al., 2017; Toklu, 2017). Thermochemical processes to produce biofuels under biomass conversion include partial oxidation with pure air or pure oxygen to produce a syngas rich in $\mathrm{CO}$ and $\mathrm{CH}_{4}$, reforming with steam to produce mixtures of $\mathrm{CO}_{2}$ and $\mathrm{H}_{2}$, partial oxidation and partial reforming with air-steam or oxygen-steam to produce a syngas rich in $\mathrm{H}_{2}$, and pure pyrolysis without any oxidizer to produce liquid and gas fuels (Hernandez et al., 2016; Pacioni et al., 2016; Kirsanovs et al., 2017; Li et al., 2017; Sansaniwal et al., 2017b; Tanczuk et al., 2017; Xiao et al., 2017; Zhang and Pang, 2017). Thus, one of the most performed thermochemical processes is coal and biomass air-gasification have been used for a long time to produce syngas with a high heating value (HHV) ranging from 4 to $6 \mathrm{MJ} / \mathrm{SATP} \mathrm{m}^{3}$ (Gordillo and Annamalai, 2010; Sandeep and Dasappa, 2014). However, in order to improve syngas quality (HHV and composition), the other gasification processes mentioned above have been studied. For instance, the use of pure oxygen as oxidizing agent instead of air enhances the energy density of the syngas produced (Kurkela et al., 2016; Hussein et al., 2017). On the other hand, biomass oxygen-steam gasification is a process used when it is required improving both gas composition and HHV of the mixtures produced.

Colombia is a country known for its coffee agroindustry and whose production of green coffee in 2016 was of 870,000 metric tons, which produced about 141,627 metric tons of coffee husk $(\mathrm{CH})$ waste. This waste can be used as feedstock for the in situ production of gaseous fuels via small-scale gasification, which can take advantage for energy generation in order to reduce the dependency of farms on fossil fuels. Updraft fixed-bed gasification technology is the most suitable for the control of the composition of the mixtures produced since the gasification stages are known as drying, pyrolysis, reduction, and combustion occur in different zones in the bed of the gasifier. Also, updraft gasifiers are very good for small-scale energy generation requirements because of its simple operation (Gordillo and Annamalai, 2010; Plis and Wilk, 2011; Sansaniwal et al., 2017a). The mixture contained in biomass releases at temperatures ranging from 373 to $450 \mathrm{~K}$ in the drying zone, placed on the top of the bed, whereas the volatile matter, contained in the dry biomass coming from the drying zone, is released at $450 \mathrm{~K}<\mathrm{T}<990 \mathrm{~K}$ in the pyrolysis zone. The char (fixed carbon and ash) produced in the pyrolysis zone downwards through the reduction zone where it reacts, at $990 \mathrm{~K}<\mathrm{T}<$ $1,100 \mathrm{~K}$, with the species $\left(\mathrm{CO}_{2}, \mathrm{CO}, \mathrm{H}_{2}, \mathrm{H}_{2} \mathrm{O}\right)$ yielded in the combustion zone to produce secondary species such as $\mathrm{CH}_{4}$, $\mathrm{CO}, \mathrm{CO}_{2}, \mathrm{H}_{2}$, etc. In the combustion zone, the remaining char from the reduction zone reacts with the oxidizing agent supplied through the plenum of the gasifier to produce the heat required in the process. The peak of temperature occurs in the combustion zone where the global heterogeneous-exothermic reactions of char with oxygen take place and release the heat required in the global gasification process. Above of the combustion zone, the temperature starts to decrease because the global reactions occurring in these zones (pyrolysis, reduction, and drying) are endothermic. Table 1 shows the global reactions occurring during a gasification process. Reactions with enthalpy lower than zero are exothermic and those with enthalpy higher than zero are endothermic.

Gordillo and Rodriguez (2011) researched adiabatic gasification and pyrolysis of coffee husk. Via simulation, the NASA CEA software was used in order to obtain the compounds and HHV of Syngas as well as the Energy Conversion Efficiency of the gasification. Among the results, it is highlighted that the syngas is rich in $\mathrm{CO}_{2}$ and $\mathrm{H}_{2}$ and the Activation Energy of coffee husk is close to $221 \mathrm{~kJ} / \mathrm{mol}$. Wilson et al. (2010) published results on a (coffee husk) $\mathrm{CH}$ gasification study, carried out at constant temperatures of 700,800 , and $900^{\circ} \mathrm{C}$ and using oxygen-nitrogen blends as an oxidizing source. The results showed that increasing both the temperature and the oxygen concentration enhances the $\mathrm{CO}$ content in mixtures, e.g., raising the temperature from 700 to $900^{\circ} \mathrm{C}$ in an environment of pure nitrogen (100\% nitrogen and $0 \%$ oxygen) and for an environment with $3 \%$ of oxygen $(97 \%$ nitrogen and $3 \%$ oxygen) on a molar basis increased the $\mathrm{CO}$ concentration in the syngas from 2.17 to $5.49 \%$ and from 3.28 to $5.93 \%$, respectively. In Van Huynh and Kong (2013) carried out an experimental study on a pilot-scale biomass gasifier using oxygen-steam as the gasifying agents. The biomasses used as feedstock to feed the gasification facility were pinewood, maple-oak mixture, and discarded seed corn. They concluded that the $\mathrm{H}_{2} / \mathrm{CO}$ ratio increases when the oxygen supplied also increased-e.g., increasing the oxygen from 21 to $40 \%$ enhanced the $\mathrm{H}_{2} / \mathrm{CO}$ ratio from 0.59 to $0.75,0.36$ to 0.43 , and 0.67 to 0.84 for pine, discarded seed corn, and maple-oak, respectively. Lenis et al. (2016) performed research on fixed-bed gasification of Jacaranda Copaia wood where air enriched with oxygen (21, 24 , and $29 \% \mathrm{vol}$ ) was used as a gasifying agent. The conclusion of these experimental results showed that an increase in the oxygen concentration raises the biomass consumption in the

TABLE 1 | Chemical reactions in the gasification process.

\begin{tabular}{|c|c|c|}
\hline & Chemical reaction & $\begin{array}{c}\Delta \mathbf{H}_{r}^{\theta} \\
{[\mathbf{k J} / \mathrm{mol}]}\end{array}$ \\
\hline $\mathrm{R}_{1}$ & $\begin{array}{l}\text { Solid Biomass } \rightarrow \text { VM }+ \text { Char }+ \text { Tar } \\
\text { Char combustion }\end{array}$ & \\
\hline $\mathrm{R}_{2}$ & $\mathrm{C}_{2}+\frac{1}{2} \mathrm{O}_{2} \rightarrow \mathrm{C}+\mathrm{CO}$ & -111 \\
\hline $\mathrm{R}_{3}$ & $\begin{array}{l}\mathrm{C}+\mathrm{O}_{2} \rightarrow \mathrm{CO}_{2} \\
\text { Char gasification }\end{array}$ & -394 \\
\hline $\mathrm{R}_{4}$ & $\mathrm{C}+\mathrm{CO}_{2} \rightarrow 2 \mathrm{CO}$ & 173 \\
\hline $\mathrm{R}_{5}$ & $\mathrm{C}+\mathrm{H}_{2} \mathrm{O} \rightarrow \mathrm{CO}+\mathrm{H}_{2}$ & 131 \\
\hline $\mathrm{R}_{6}$ & $\begin{array}{l}\mathrm{C}+2 \mathrm{H}_{2} \rightarrow \mathrm{CH}_{4} \\
\text { Homogeneous reactions }\end{array}$ & -75 \\
\hline $\mathrm{R}_{7}$ & $\mathrm{CO}+\frac{1}{2} \mathrm{O}_{2} \rightarrow \mathrm{CO}_{2}$ & -283 \\
\hline $\mathrm{R}_{8}$ & $\mathrm{H}_{2}+\frac{1}{2} \mathrm{O}_{2} \rightarrow \mathrm{H}_{2} \mathrm{O}$ & -242 \\
\hline $\mathrm{R}_{9}$ & $\mathrm{CH}_{4}+2 \mathrm{O}_{2} \rightarrow \mathrm{CO}_{2}+2 \mathrm{H}_{2} \mathrm{O}$ & -803 \\
\hline $\mathrm{R}_{10}$ & $\mathrm{CO}+\mathrm{H}_{2} \mathrm{O} \rightarrow \mathrm{CO}_{2}+\mathrm{H}_{2}$ & -41 \\
\hline $\mathrm{R}_{11}$ & $\mathrm{CH}_{4}+\mathrm{H}_{2} \mathrm{O} \rightarrow \mathrm{CO}+3 \mathrm{H}_{2}$ & 206 \\
\hline
\end{tabular}

Adapted from Gírio et al. (2010), Bilgili et al. (2017), and Toklu (2017). 
gasifier due to lower nitrogen amount, which reduces syngas thermal energy losses by heating of nitrogen. In Liu et al. (2018) carried out experimental research on a two-stage fluidized bed gasifier using oxygen-enriched air as gasifying agent and rice straw as fuel. The oxygen concentrations of the gasifying agent were from 21 up to $45 \%$. Thus, the findings present that increasing the oxygen concentration is conducive to raising the gasification temperature, leading to enhancement of the HHV of syngas (4-5.24 MJ/kg) and improving the gasification efficiency. A secondary oxygen injection of $33 \%$ of primary oxygen reduced the tar concentration from 15.78 to 10.24 $\mathrm{g} / \mathrm{Nm}^{3}$. Bonilla and Gordillo (2017) performed experimental research on autothermal gasification of $\mathrm{CH}$ using air-steam blends as gasifying agents. In their research, Equivalence Ratio (ER) and Steam-Fuel Ratio (SF) were the parameters set which ranged 1.53-6.11 and 0.23-0.89, respectively. The HHV of the syngas obtained was between 3,112 and 5,085 $\mathrm{kJ} / \mathrm{SATP} \mathrm{m}^{3}$. The main chemical composite concentrations (\%) of syngas on a dry basis at its maximum $\mathrm{HHV}$ were $\mathrm{H}_{2}=18.81, \mathrm{CO}=10.13, \mathrm{CO}_{2}$ $=19.33$, and $\mathrm{CH}_{4}=3.52$. The results evidence that even though supplying steam into the gasifier decreases the main temperature of the fixed-bed, the HHV of syngas increases.

A literature review shows that there are no previous studies on fixed bed counter-flow gasification of $\mathrm{CH}$ using oxygensteam mixtures as an oxidizing source. Also, the previous study on biomass gasification (Gordillo and Rodriguez, 2011) with nitrogen-oxygen showed only the effect of increasing the oxygen (21-40\%) on the $\mathrm{H}_{2} / \mathrm{CO}$ ratio. Thus, this paper presents results from a study carried out in fixed-bed counter-flow gasification of $\mathrm{CH}$ using oxygen-steam as an oxidizing agent. As a principal contribution, this study discusses the effect of operating parameters such as Equivalence Ratio (ER) and Steam-Oxygen ratio $(\mathrm{SF})$ on temperature profiles along the gasifier axis, syngas composition, syngas HHV, and Cold Gas Efficiency (CGE), and Total Energy Improvement Ratio (TEIR). Also, the results are compared to results previously published (Bonilla and Gordillo, 2017) on gasification of $\mathrm{CH}$ but using air-steam mixtures as an oxidizing agent. The thermochemical characterization (empirical formula, DAF-HHV, formation enthalpy, etc.) of the $\mathrm{CH}$ also is presented. ER and SF are defined in Equations (1) and (2), respectively.

$$
\begin{aligned}
\mathrm{ER} & =\frac{\text { stoichiometric oxygen moles }}{\text { actual oxygen moles }} \\
\mathrm{SF} & =\frac{\text { actual steam moles }}{\text { actual fuel moles }}
\end{aligned}
$$

The Equivalence Ratio is defined according to the USA definition.

\section{MATERIALS AND EXPERIMENTAL METHOD}

\section{Fuel Biomass}

$\mathrm{CH}$ samples were obtained from Colombian agroindustry and characterized under proximate and ultimate analysis. The samples were prepared under the ASTM D2013 standard as required for the proximate analysis, which were carried out under the following standards: moisture (ASTM D3302), volatile matter (ASTM D3175/D7582), ash content (ASTM D4239), fixed carbon (ASTM D3172), sulfur (ASTM 2492), high heating value (ASTM D5865). The elemental analysis was done as follows: carbon, hydrogen, and nitrogen (ASTM D5373), sulfur (ASTM 2492), ashes (ASTM D3174-12/D7582-15). Also, the particle size of the biomass was determined by using the ASTM D422.

\section{Experimental Setup and Procedure}

Figure 1 shows the experimental facility where the experimentation was developed. It is a low-scale (about 10 $\mathrm{kW}$ ) counter-flow fixed-bed gasifier that can use air-steam or oxygen-steam blends as an oxidizing source. The main facility components are (i) fixed-bed gasifier, (ii) biomass hoper, (iii) temperature data logger, (iv) pneumatic vibrator coupled to the grate, (v) steam generator, (vi) gas cleaning system, (vii) a gas analyzer (GS), and (viii) syngas burner.

(i) The fixed-bed gasifier is $1 \mathrm{~m}$ height and built of a castable alumina refractory tube whose inner and outer diameters are 127 and $254 \mathrm{~mm}$, respectively. The tube is surrounded by a $5 \mathrm{~cm}$ insulating fiberglass blanket layer to reduce the heat loss. The biomass hopper has a worm screw in the bottom to feed the biomass continuously. The temperature data logger (Omega RD8800) records every minute the temperature obtained from $8 \mathrm{k}$-type thermocouples placed along the axis of the bed in a way that it gives the profile of the temperature along the gasifier bed. The steam generator is built of a $10 \mathrm{~cm}$ stainless steel tube surrounded by an electric tape resistance with variable power from 350 to $1,000 \mathrm{~W}$. The tube and resistance are externally isolated with a $10-\mathrm{cm}$ layer of fiberglass blanket to avoid heat loss. The mass rate of vapor generated in this device depends on the power supplied by the electrical resistance and varies from 1.3 to $17.3 \mathrm{~g} / \mathrm{min}$. The oxygen volumetric flows supplied to the gasifier were measured by an oxygen flowmeter (Dwyer), whereas the steam flows were measured using a certificated calibrated rotameter (Aalborg P11A1-VA0). The pneumatic vibrator is joined to the conical cast grate to maintain continuous ash removal from the bed to gasifier plenum, placed under the grate at gasifier bottom. The cleaning gas system has a moisture and tar collector that are preceded by a set of filters to retain the particle material flowing with the syngas. Samples of the clean syngas leaving the filters are taken to the gas analyzer (Gasboard-3100 Infrared Syngas), which analyzes the mole fraction of $\mathrm{H}_{2}, \mathrm{CO}$, $\mathrm{CO}_{2}, \mathrm{CH}_{4}$, and $\mathrm{C}_{\mathrm{n}} \mathrm{H}_{\mathrm{m}}$ between the following ranges: $0<\mathrm{CO} 2<$ $50 \%, 0<\mathrm{CO}<100 \%, 0<\mathrm{CH}_{4}<10 \%, 0<\mathrm{H}_{2}<50 \%$, and 0 $<\mathrm{C}_{\mathrm{n}} \mathrm{H}_{\mathrm{m}}<10 \%$. Gas samples analyzed are mixed downstream, with the remaining syngas to be burned in the syngas burner.

\section{Operating Conditions}

The experiments were carried out according to the parameters specified in Table 2 and under the following sequence: (i) the gasifier grate was heated at $550^{\circ} \mathrm{C}$ using a torch, (ii) the gasifier plenum was closed and the temperature recorder was turned on in order to store temperature every minute, (iii) the bed was fed with biomass until the bed height was $16 \mathrm{~cm}$, (iv) the flows of steam and oxygen were adjusted as required for each experiment (ER, and SF), (v) the fed biomass continued as it 


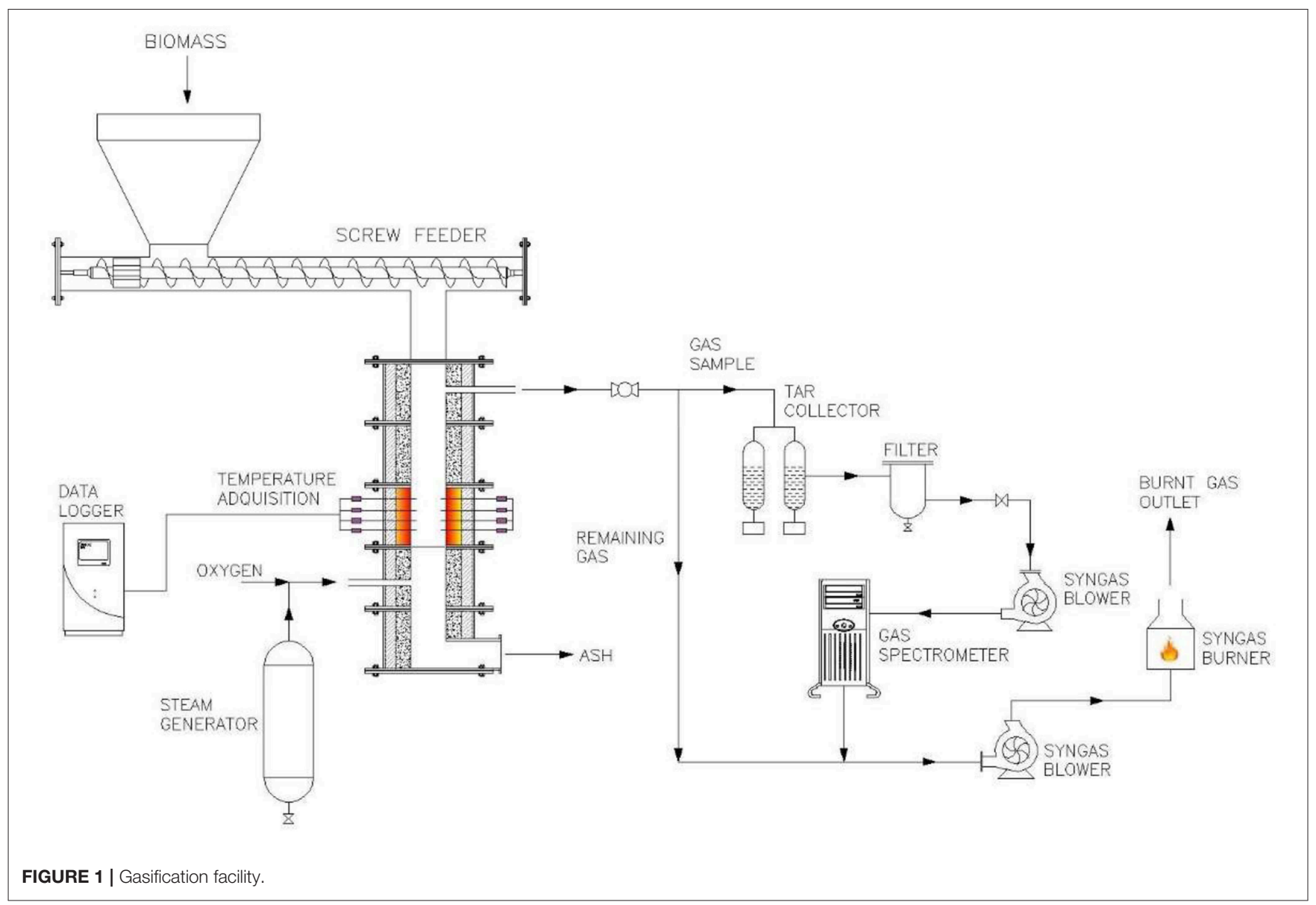

TABLE 2 | Experimental parameters.

\begin{tabular}{ll}
\hline Oxygen pressure and temperature & $0.76 \mathrm{bar}, 18^{\circ} \mathrm{C}$ \\
Steam pressure and temperature & $0.76 \mathrm{bar}, 92^{\circ} \mathrm{C}$ \\
Bed height & $160 \mathrm{~mm}$ \\
Fuel biomass & Coffee husk \\
Particle size & Flake where $80 \%$ of the mass \\
& is $\mathrm{d}_{\mathrm{p}}<4 \mathrm{~mm}$ \\
Biomass flow rate & $0.166 \mathrm{~g} / \mathrm{s}(600 \mathrm{~g} / \mathrm{h})$ \\
Oxygen flow & $15 \mathrm{SFCH}-4 \mathrm{SFCH}$ \\
& $\left(0.42 \mathrm{SATP} \mathrm{m}^{3} / \mathrm{h}-0.11 \mathrm{SATP} \mathrm{m}^{3} / \mathrm{h}\right)$ \\
Steam flow & $2.18-4.99 \mathrm{~g} / \mathrm{min}$ \\
& $(130.8-299.4 \mathrm{~g} / \mathrm{h})$ \\
ER & $1.49-5.59$ \\
SF & $0.38-0.87$ \\
\hline
\end{tabular}

was burned until the gasifier was at almost steady-state, i.e., peak temperature at the bed did not change, (vi) the syngas samples were carried out toward a gas analyzer at a flow rate of $11 / \mathrm{min}$ to be analyzed, (vii) the samples analyzed and the syngas remaining were fixed downstream and burned in the gas burner, (viii) the sample analysis continued at real time during $10 \mathrm{~min}$, (ix) the biomass screw feeder was stopped and the gasifier cooled down until room conditions, $(\mathrm{x})$ char samples were taken from the gasifier plenum to be analyzed, and (xi) all systems compounding the experimental facility were cleaned to prepare the facility for the next experiment. All experimentation was carried out at $P=76 \mathrm{kPa}$ and temperatures of oxygen and steam of 18 and $92^{\circ} \mathrm{C}$, respectively.

\section{RESULTS AND DISCUSSION Biomass Characteristics}

Table 3 shows the results on ultimate, proximate, lignocellulose analyses, the biomass empirical formula and formation enthalpy as well as the particle size distribution of $\mathrm{CH}$. The empirical formula was determined based on the atom balance on components given by proximate and ultimate analyses, whereas the formation enthalpy was derived using the dry ash-free high heating value (DAF HHV) in order to perform an energy balance between reactants and products of the theoretical combustion of a $\mathrm{kmol}$ of biomass defined as the empirical formula $\left(\mathrm{CH}_{1.63} \mathrm{~N}_{0.015} \mathrm{O}_{0.82} \mathrm{~S}_{0.0024}\right)$.

Proximate analysis results show that the $\mathrm{CH}$ has a high volatile matter content, which makes this biomass a good feedstock for gasification processes in order to produce clean fuels. Due to its dry ash-free high heating value $(21,217 \mathrm{~kJ} / \mathrm{kg}), \mathrm{CH}$ is 
TABLE 3 | Characterization of $\mathrm{CH}$.

\begin{tabular}{ll}
\hline Proximate analysis & \\
Moisture \% & 10.10 \\
Volatiles \% & 79.86 \\
Ash \% & 1.20 \\
FC \% & 8.84 \\
Ultimate analysis & \\
$\mathrm{C} \%$ & 44.52 \\
$\mathrm{H} \%$ & 6.03 \\
$\mathrm{~N} \%$ & 0.78 \\
$\mathrm{O} \%$ & 48.38 \\
$\mathrm{~S} \%$ & 0.29 \\
$\mathrm{HHV}(\mathrm{kJ} / \mathrm{kg})$ & 18,740 \\
$\mathrm{DRY} \mathrm{HHV}(\mathrm{kJ} / \mathrm{kg})$ & 20,845 \\
DAF HHV (kJ/kg) & 21,127 \\
Empirical formula & $\mathrm{CH} 1.63 \mathrm{~N}_{0.015} \mathrm{O}_{0.82} \mathrm{~S}_{0.0024}$ \\
Enthalpy formation (kJ/mol) & $-103,957$ \\
Analysis of lignocellulose & \\
Cellulose \% & 30.12 \\
Hemicellulose \% & 15.90 \\
Lignin \% & 27.87 \\
Particle size & \\
[0,0; 0,5] mm & $13.15 \%$ \\
{$[0,5 ; 1,0] \mathrm{mm}$} & $14.01 \%$ \\
{$[1,0 ; 1,7] \mathrm{mm}$} & $20.54 \%$ \\
{$[1,7 ; 2,0] \mathrm{mm}$} & $9.94 \%$ \\
{$[2,0 ; 2,8] \mathrm{mm}$} & $20.6 \%$ \\
{$[2,8 ; 4,0] \mathrm{mm}$} & $19.33 \%$ \\
{$[4,0 ; 5,6] \mathrm{mm}$} & $2.33 \%$ \\
\hline & \\
\hline & \\
\hline
\end{tabular}

appropriate for combustion processes to produce heat or for gasification process with steam-oxygen mixtures rich in steam without heat supply. More steam supplied to the gasifier implies low gasification temperatures. In gasification processes when the temperature is very low, the gasification process is not sustainable by itself and requires heat addition.

\section{Uncertainty Analysis}

The uncertainty in the flows of oxygen, steam, biomass fuel, and syngas composition was estimated according to Equations (3) and (4), which give the total uncertainty and the uncertainty propagation, respectively.

$$
\begin{aligned}
\sigma_{x_{i}}^{2} & =B_{x_{i}}^{2}+P_{x_{i}}^{2} \\
\sigma_{r}^{2} & =\sum_{i=1}^{j}\left(\frac{\partial r}{\partial x_{i}}\right)^{2} \sigma_{x_{i}}^{2}
\end{aligned}
$$

Where, $B_{x_{i}}$ and $P_{x_{i}}$ are systematic uncertainties and random uncertainties of $x_{i} ; r=r\left(x_{1}, x_{2}, \ldots, x_{2}\right)$ is function of $x_{i}$ measured variables of $j ; \sigma_{r}, \sigma_{x_{i}}$ are uncertainties of $r$ and $\mathrm{x}_{\mathrm{i}}$, respectively. The temperature was tested with thermocouples of the accuracy of $\pm 0.75 \%$. The uncertainty derived from thermocouple operation was $\pm 0.15 \%$ which gives an uncertainty total, given by Equation 4 , in temperature, of $\pm 0.76 \%$. The oxygen flow rate was measured by a rotameter with $20 \mathrm{SFCH}$ full scale $\left(0.57 \mathrm{~m}^{3} / \mathrm{h}\right), 1 \mathrm{SFCH}\left(0.0285 \mathrm{~m}^{3} / \mathrm{h}\right)$ of resolution, and accuracy of $\pm 4 \%$; the total uncertainty of airflow, given by Equation (3), was $\pm 4 \%$. Steam flows entering the gasifier were measured with a rotameter of $9.96 \mathrm{~cm}^{3} / \mathrm{min}$ full scale, $0.066 \mathrm{~cm}^{3} / \mathrm{min}$ resolution, and an accuracy $\pm 1 \%$. Thus, total uncertainty to water flow rate measurement was $\pm 1 \%$. The feeding system (screw feeder) was calibrated previously and its systematic uncertainty was $\pm 3.42 \%$. The total uncertainty of scale used to measure the sample weight was $\pm 1 \%$, and the total uncertainty of the timer used to measure the feed rate was $\pm 3.87 \%$. The uncertainties of ER and SF are functions of two variables, which were calculated by using Equation (4), resulting in $\pm 5.57 \%$ for ER and $\pm 4.12 \%$ for the SF ratio. The total uncertainty about syngas compounds measured by a mass spectrometer was $\pm 1 \%$ accuracy only.

\section{Temperature Profiles Along the Gasifier Axis}

Figures 2-4 show the temperature profiles along the gasifier axis for different SF and ER ratios. The temperature curves show that the temperature peak occurred at about $4 \mathrm{~cm}$ above of the grate, indicating the midpoint of the combustion zone where the char reacts with the oxygen-steam mixture supplied, releasing $\mathrm{CO}$ and $\mathrm{CO}_{2}$ via the oxidation of $\mathrm{C}$ $\left(\mathrm{C}+\frac{1}{2} \mathrm{O}_{2} \rightarrow \mathrm{CO}, \mathrm{C}+\mathrm{O}_{2} \rightarrow \mathrm{CO}_{2}\right)$ and $\mathrm{H}_{2}$ and $\mathrm{CO}$ via the Carbon steam reforming reaction $\left(\mathrm{C}+\mathrm{H}_{2} \mathrm{O} \rightarrow \mathrm{H}_{2}+\mathrm{CO}\right)$. Also, the heat required to drive the gasification process is released in the combustion zone by the oxidation of C. Downstream of the combustion zone (height $>4 \mathrm{~cm}$ ), the trend of the temperature curves is decreasing since almost all the oxygen supplied to the gasifier is consumed in the combustion zone, and hence the reactions occurring over there are endothermic. Immediately above the combustion zone is the pyrolysis zone, where the volatile matter contained in biomass is released as a mixture of gases composed basically of $\mathrm{CO}, \mathrm{CO}_{2}, \mathrm{H}_{2} \mathrm{O}$, $\mathrm{H}_{2}, \mathrm{CH}_{4}, \mathrm{C}_{2} \mathrm{H}_{6}$, and other heavier gases. Above the pyrolysis zone, one of the more important reactions is the shift reaction $\left(\mathrm{CO}+\mathrm{H}_{2} \mathrm{O} \rightarrow \mathrm{H}_{2}+\mathrm{CO}_{2}\right.$ ), in which the $\mathrm{CO}$ coming from the combustion and pyrolysis zone reacts with the steam released in the dry zone to produce more $\mathrm{H}_{2}$ and $\mathrm{CO}_{2}$. In general, pyrolysis and drying processes are endothermic, consuming an amount of the heat produced in the combustion zone.

Figures 2, 3 show the effect of the ER on the temperature profiles. All curves show that increased ER tends to decrease the temperature along the gasifier axis. i.e., the pick temperature $\left(T_{p}\right)$ that occurs in the combustion zone decreases with increased ER (lower oxygen supplied). Lower oxygen in the combustion zone implies poor oxidation of $\mathrm{C}$ (rich oxidation) and hence a lower heat released-i.e., at $\mathrm{SF}=0.4$, increasing the ER from 1.6 to 5.6 decreases the peak temperature from 979 to $864^{\circ} \mathrm{C}$. Also, results show that the increase in SF decreases temperature along the gasifier. Increased SF implies more steam supplied to the gasifier and hence the steam reforming reactions, which in general are endothermic, are favored-i.e., at $\mathrm{ER}=1.6$, the peak temperature is $979^{\circ} \mathrm{C}$ for a $\mathrm{SF}=0.4$ whereas it is $825^{\circ} \mathrm{C}$ for a $\mathrm{SF}=0.8$. 
A

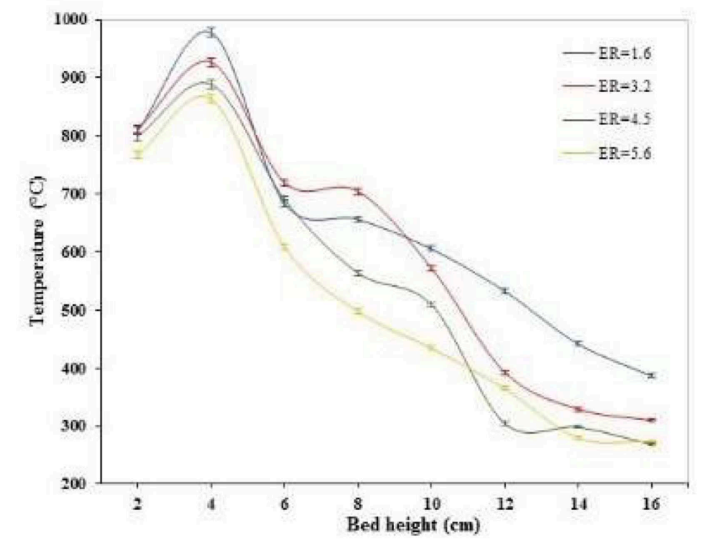

B

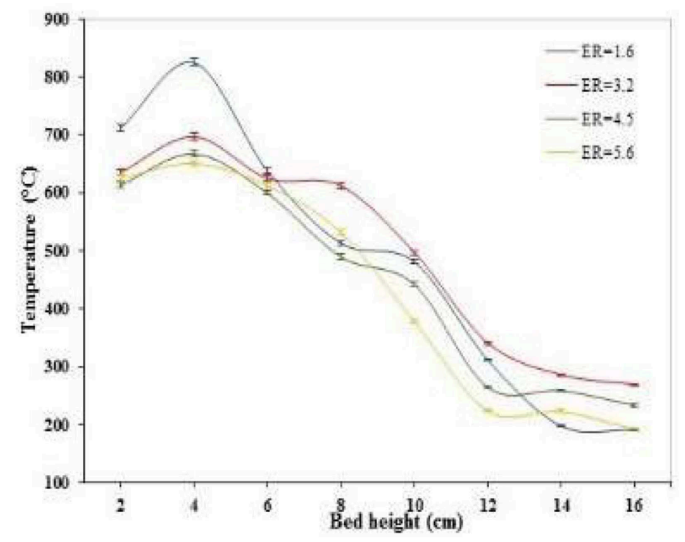

FIGURE 2 | Temperature profile along of gasifier bed axis at (A) SF $=0.4$; $\mathbf{( B )}$ SF =0.8.

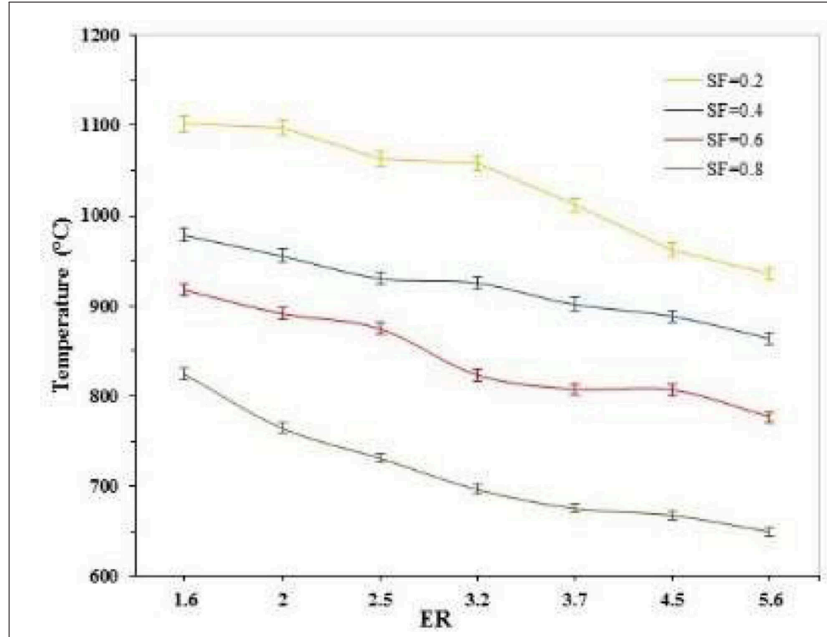

FIGURE 3 | Temperature peaks vs. ER for several SF ratio values for air and oxygen gasification of $\mathrm{CH}$.

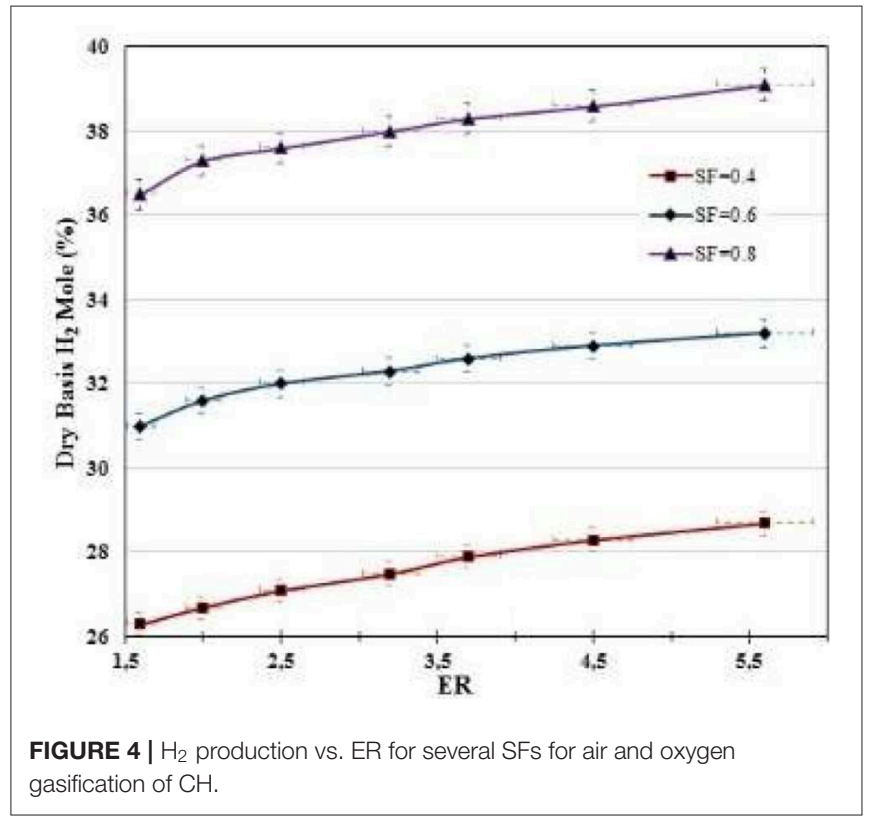

oxygen, due to increased ER, the carbon burnt decreases, leading a lower heat release.

\section{Syngas Composition}

Figures 4-7 show the percentages of $\mathrm{H}_{2}, \mathrm{CO}, \mathrm{CO}_{2}$, and $\mathrm{CH}_{4}$ contents in syngas as a function of ER and SF ratios. As shown in Figure 4, $\mathrm{H}_{2}$ content increases as ER and SF increase. At constant SF, the $\mathrm{H}_{2}$ curves tend to be linear with ER for ER $>$ 1.75. i. e., at $\mathrm{SF}=0.4$, increasing the ER from 1.6 to 5.6 raises the $\mathrm{H}_{2}$ content from 26.3 to $28.7 \%$, which corresponds to an increase of the $\mathrm{H}_{2}$ production of $9.12 \%$. However, at $\mathrm{SF}=0.8$, for the same increase in ER (1.6-5.6) the increase in $\mathrm{H}_{2}$ content $(36.5-39.1 \%)$ is only $7.1 \%$. This implies that at higher SF the effect of the ER on the $\mathrm{H}_{2}$ production tends to 


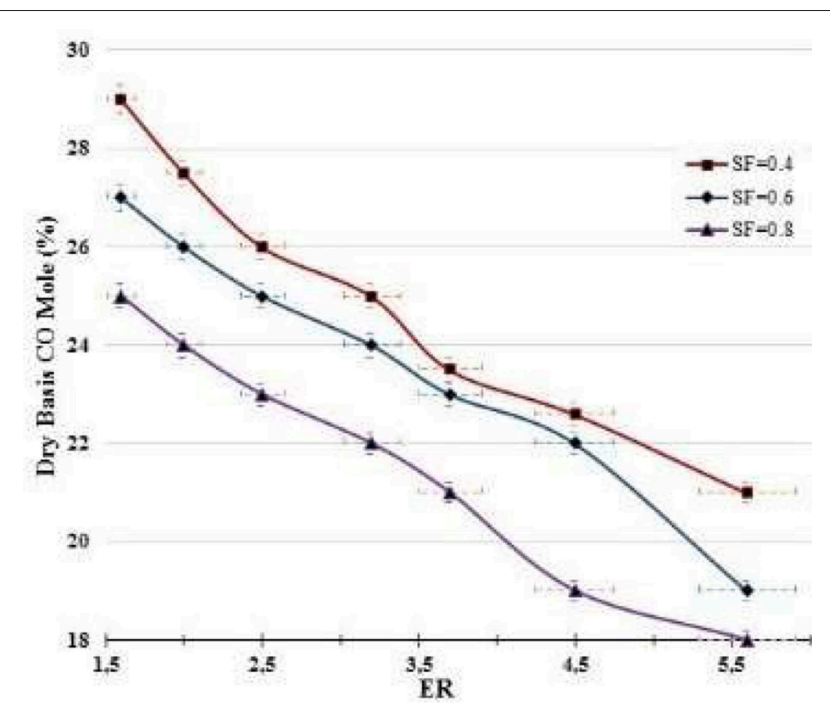

FIGURE 5 | CO concentration vs. ER at several SF values.

be less important. At constant SF, increased ER leads to lower oxygen entering the gasifier and hence the combustion of char in the combustion zone $\left(\mathrm{C}+\mathrm{O}_{2} \rightarrow \frac{1}{2} \mathrm{CO}, \mathrm{C}+\mathrm{O}_{2} \rightarrow \mathrm{CO}_{2}\right)$ occurs in a poor oxygen ambient, which favors the production of $\mathrm{CO}$ instead of $\mathrm{CO}_{2}$. More $\mathrm{CO}$ produced in the combustion zone by partial oxidation of $\mathrm{C}$ implies more production of $\mathrm{H}_{2}$ through the reaction of $\mathrm{CO}$ with both the steam supplied to the gasifier and the moisture released in the drying zone $\left(\mathrm{CO}+\mathrm{H}_{2} \mathrm{O} \rightarrow \mathrm{H}_{2}+\mathrm{CO}_{2}\right)$. Thus, $\mathrm{H}_{2}$ production starts in the combustion zone and continues through the other zones (reduction, pyrolysis, and drying). Figure 4 also shows the effect of $\mathrm{SF}$ on $\mathrm{H}_{2}$ production. At constant ER, the effect of increasing $\mathrm{SF}$ is to produce more $\mathrm{H}_{2}$ due to more steam supply with the oxidizing source, which favors the shift reaction $\left(\mathrm{CO}+\mathrm{H}_{2} \mathrm{O} \rightarrow \mathrm{H}_{2}+\mathrm{CO}_{2}\right)$ and carbon reforming reaction $\left(\mathrm{C}+\mathrm{H}_{2} \mathrm{O} \rightarrow \mathrm{H}_{2}+\mathrm{CO}\right)$-i.e., at $\mathrm{ER}=1.6$, rising $\mathrm{SF}$ from 0.4 to 0.8 increases the $\mathrm{H}_{2}$ production from 26.3 to $36.5 \%$, which corresponds to an increase of $38.8 \%$, whereas at $\mathrm{ER}=5.5$ the same increase in SF (0.4-0.8) increases the production of $\mathrm{H}_{2}$ by $36.2 \%$ (from 28.7 and $39.1 \%$ ). This suggests that the effect of SF on the $\mathrm{H}_{2}$ is almost linear for the ranges of the ER $(1.6 \leq \mathrm{ER} \leq$ 5.6) and $\mathrm{SF}(0.4 \leq \mathrm{SF} \leq 0.6)$ studied.

Figure 5 shows the effect of the ER and SF ratios on the $\mathrm{CO}$ production. The trend of the curves is to decrease with increased both ER and SF. Increased SF implies more steam free downstream the combustion zone, which favors the shift reaction $\left(\mathrm{CO}+\mathrm{H}_{2} \mathrm{O} \rightarrow \mathrm{H}_{2}+\mathrm{CO}_{2}\right)$ that consumes more of the $\mathrm{CO}$ produced by the carbon steam reforming reaction $\left(\mathrm{CO}+\mathrm{H}_{2} \mathrm{O} \rightarrow \mathrm{H}_{2}+\mathrm{CO}_{2}\right)$ in the combustion zone. At constant SF, increasing ER leads to a combustion zone poor in oxygen concentration, with partial oxidation of carbon (C) producing $\mathrm{CO}$ since the combustion of char is almost diffusioncontrolled (Hernández et al., 2012). At much higher ER, the gasification process tends to be near to pyrolysis, in which more of the species produced are due to the volatilization of volatile matter contained in biomass. Also, increased ER decreases the

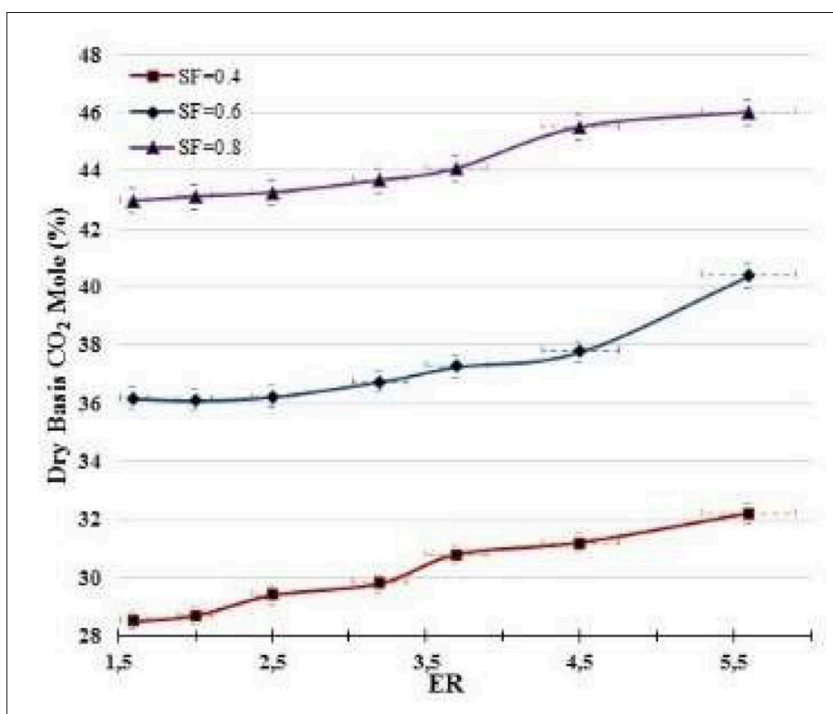

FIGURE 6 | $\mathrm{CO}_{2}$ concentration at several SF vs. ER.

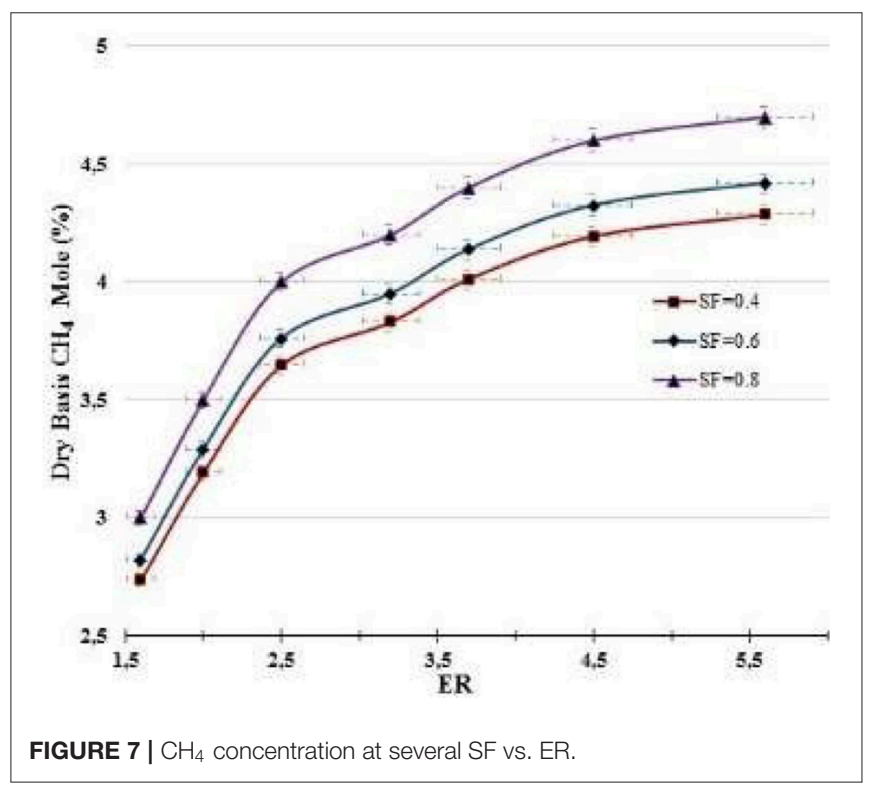

temperature peak in the combustion zone where the oxidation of carbon occurs, which disfavors the reaction $\mathrm{C}_{2}+\mathrm{O}_{2} \rightarrow 2 \mathrm{CO}$, since it is more important at $\mathrm{T}>800^{\circ} \mathrm{C}$ than that of the carbon $\left(\mathrm{C}+\mathrm{O}_{2} \rightarrow \mathrm{CO}_{2}\right)$ to produce $\mathrm{CO}_{2}$.

Figure 6 illustrates that an oxidizer source richer in $\mathrm{H}_{2} \mathrm{O}$ (increased SF) and poorer in $\mathrm{O}_{2}$ (decreased ER) produces syngas with higher $\mathrm{CO}_{2}$ content. More $\mathrm{H}_{2} \mathrm{O}$ supplied to the gasifier implies a combustion zone with a high $\mathrm{H}_{2} \mathrm{O}$ concentration, which favors the carbon reforming reaction $\left(\mathrm{C}+\mathrm{H}_{2} \mathrm{O} \rightarrow \mathrm{H}_{2}+\mathrm{CO}\right)$ that produces $\mathrm{CO}$ and $\mathrm{H}_{2}$. Also, environments richer in both $\mathrm{H}_{2} \mathrm{O}$ and $\mathrm{CO}$ favor the shift reaction $\left(\mathrm{CO}+\mathrm{H}_{2} \mathrm{O} \rightarrow \mathrm{H}_{2}+\mathrm{CO}_{2}\right)$, which consumes $\mathrm{CO}$ to produce $\mathrm{CO}_{2}$ downstream the combustion zone. 
In general, from results presented in Figures 5, 6, it is apparent that under the parametric experimental conditions in which the research was developed the shift reaction $\left(\mathrm{CO}+\mathrm{H}_{2} \mathrm{O} \rightarrow \mathrm{H}_{2}+\mathrm{CO}_{2}\right)$ was more important than the Boudouard reaction $\left(\mathrm{C}+\mathrm{CO}_{2} \rightarrow 2 \mathrm{CO}\right)$. Shift and Boudouard reactions are competitive for $\mathrm{CO}$ and $\mathrm{CO}_{2}$ productions. Also, Boudouard reaction is dominant at extremely high temperatures or when the $\mathrm{O}_{2}$ concentration is very low (Hernández et al., 2012).

Methane production is shown in Figure 7 for different ER and $\mathrm{SF}$ ratios. In general, the production of $\mathrm{CH}_{4}$ was below $5 \%$. Increasing both ER and SF enhances the production of $\mathrm{H}_{2}$ (Figure 4) and hence the production of $\mathrm{CH}_{4}$ through the reaction $\left(\mathrm{C}+2 \mathrm{H}_{2} \rightarrow \mathrm{CH}_{4}\right)$, occurring in the reduction zone, which is important at extremely high temperature or at high $\mathrm{H}_{2}$ concentration.

\section{HHV of Syngas}

The Syngas High Heating Values $\left(\mathrm{HHV}_{\text {syngas }}\right)$ or energy density of syngas was calculated using Equation (5).

$$
H H V_{\text {syngas }}=\sum_{i=1}^{j} X_{i} \cdot H H V_{i}
$$

where, $X_{i}$ and $H H V_{i}$ are the molar fraction and high heating value of each gas fuel, contained in syngas, respectively. $\mathrm{HHV}_{\text {syngas }}$ is the high heating value ( $\mathrm{kJ} / \mathrm{SATP} \mathrm{m}^{3}$ of dry syngas). Table 4 presents the syngas energy density in a dry base for the operating parameters (ER and SF) used during the experimentation. At constant SF, the energy density of the syngas increases with increased ER until ER $=2.5$, where it starts to decrease as the ER increases. On the other hand, at constant ER the increase in SF always increases the syngas energy density. As SF increases, the production of $\mathrm{CH}_{4}$ and $\mathrm{H}_{2}$ increases although the production of CO decreases. The syngas energy density is strongly affected by the production of $\mathrm{CH}_{4}$ which is a gas that has the highest $\mathrm{HHV}$ as compared to other species in the syngas produced-i.e., the $\mathrm{CH}_{4}$ energy density is $36,264 \mathrm{~kJ} / \mathrm{SATP} \mathrm{m}^{3}$ while those of the $\mathrm{CO}$ and $\mathrm{H}_{2}$ are 12,048 and $12,123 \mathrm{~kJ} / \mathrm{SATP} \mathrm{m}^{3}$, respectively. The syngas HHV ( $\mathrm{HHV}_{\text {syngas }}$ ) was 7,625-8,841 kJ/SATP ${ }^{3}$, which corresponds to 21.0 and $24.4 \%$ of the methane-HHV.

\section{Energy Recovery}

Although $\mathrm{HHV}_{\text {syngas }}$ gives information on the energy density of the syngas produced, it does not provide information about the energy recovered per biomass unit gasified. Cold gas efficiency
(CGE) or energy recovery typically is a parameter used to estimate the energy recovered in syngas (room conditions) per unit of biomass gasified. The recovery energy fraction in the syngas is calculated using Equation (6), the remaining energy is in char, tar, and syngas sensible heat.

$$
\begin{aligned}
& C G E_{\text {net }} \\
& =\frac{\dot{\forall}_{\text {syngas }} \cdot H H V_{\text {syngas }}}{\dot{m}_{\text {biomass }} \cdot H H V_{\text {biomass }}+\dot{m}_{\text {steam }} \cdot \Delta h_{\text {water-steam }}+\dot{\forall}_{\text {oxygen }} \cdot E V_{\text {oxygen }}}
\end{aligned}
$$

Where, $C G E_{n e t}$ is the net Cold Gas Efficiency or energy recovery, $\dot{\forall}_{\text {syngas }}\left(\mathrm{m}^{3} / \mathrm{h}\right)$ is the syngas flow, $H H V_{\text {syngas }}\left(\mathrm{kJ} / \mathrm{m}^{3}\right)$ is syngas density on a dry basis, $\dot{m}_{\text {biomass }}(\mathrm{kg} / \mathrm{h})$ is the mass of $\mathrm{CH}$ gasified per hour, $H H V_{\text {biomass }}(\mathrm{kJ} / \mathrm{kg})$ is the Higher Heating Value of DAF-CH, $\dot{m}_{\text {steam }}(\mathrm{kg} / \mathrm{h})$ is the mass rate of steam supplied to the gasifier, $\Delta h_{\text {water-steam }}$ is the difference of specific enthalpy $(\mathrm{kJ} / \mathrm{kg})$ between steam $\left(0.76 \mathrm{bar}, 92^{\circ} \mathrm{C}\right)$ and water $(0.76 \mathrm{bar}$, $\left.20^{\circ} \mathrm{C}\right), \dot{\forall}_{\text {oxygen }}$ is the supplied flow of oxygen $\left(\mathrm{m}^{3} / \mathrm{h}\right)$ entering into the gasifier, and $E V_{\text {oxygen }}$ is the energetic value of oxygen $(1,129$ $\mathrm{kJ} / \mathrm{m}^{3}$ ) (Cerone et al., 2016).

Figure 8 presents the $C G E_{n e t}$ at constant SF, the $C G E_{n e t}$ always decreases as ER values increase. Increased ER increases the production of char due to lower oxygen available in the

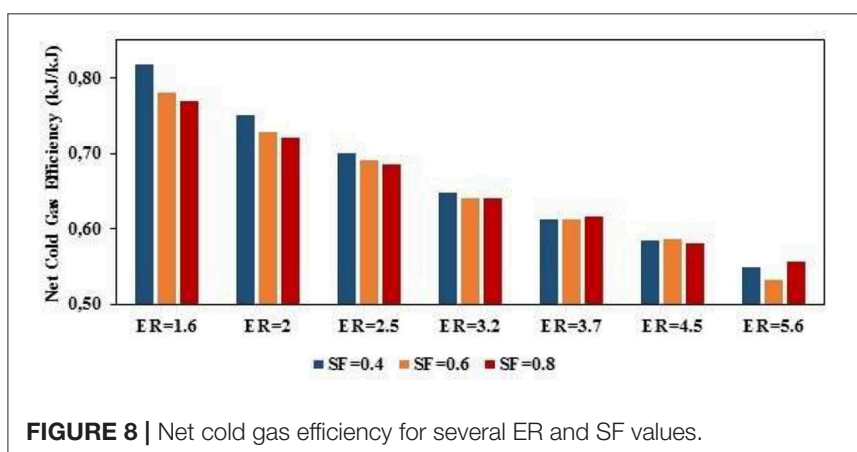

TABLE 5 | Model summarize.

\begin{tabular}{lccccc}
\hline Fuel gas & $\mathbf{R}$ & $\mathbf{R}^{2}$ & Adjusted $\mathbf{R}^{2}$ & $\begin{array}{c}\text { Standard error } \\
\text { of the estimate }\end{array}$ & Durbin-Watson \\
\hline $\mathrm{CO}$ & 0.990 & 0.981 & 0.979 & 0.41937 & 1.363 \\
$\mathrm{H}_{2}$ & 0.998 & 0.996 & 0.995 & 0.30434 & 0.700
\end{tabular}

TABLE 4 | HHV of syngas [kJ/SATP $\left.\mathrm{m}^{3}\right]$.

\begin{tabular}{cccccccc}
\hline SF & \multicolumn{7}{c}{ ER } \\
\cline { 2 - 7 } & $\mathbf{1 . 6}$ & $\mathbf{2 . 0}$ & $\mathbf{2 . 5}$ & $\mathbf{3 . 2}$ & $\mathbf{3 . 7}$ & $\mathbf{4 . 5}$ \\
\hline 0.4 & 7,714 & 7,753 & 7,793 & 7,790 & 7,726 & 7,735 \\
0.6 & 8,074 & 8,204 & 8,309 & 8,296 & 8,283 & 8,269 \\
0.8 & 8,568 & 8,733 & 8,837 & 8,841 & 8,832 & 7,625 \\
& & & & & & 8,703
\end{tabular}


combustion zone for the combustion of char-i.e., when the ER tends to zero the gasification process tends to be pure pyrolysis, in which the syngas produced corresponds to the volatile matter content in biomass. At $\mathrm{ER} \geq 3.2$, the effect of the SF ratio on energy recovery is to increase. In general, increased SF tends to produce syngas with higher $\mathrm{HHV}$ due to more production of both $\mathrm{CH}_{4}$ and $\mathrm{H}_{2}$. Increased $\mathrm{SF}$ implies more $\mathrm{H}_{2} \mathrm{O}$ in the combustion zone, which favors the char steam reforming reaction and hence more char consumed to produce $\mathrm{H}_{2}$ and $\mathrm{CO}$ and lower char in gasifier plenum. The energy recovery ranged between 53 and $82 \%$.

\section{Multiple Linear Model for $\mathrm{CO}$ and $\mathrm{H}_{2}$ Concentration}

Since the behavior of $\mathrm{CO}$ and $\mathrm{H}_{2}$ concentration as a function of ER is near to that of a straight line for several SF values, the hypothesis of a linear function of $\mathrm{CO}$ concentration which depends on ER and SF was evaluated in the current study. Thus, a statistic model under multiple linear regression conditions was performed in the software IBM ${ }^{\circledR}$ SPSS ${ }^{\circledR}$ STATISTICS 24 where the results that confirm the viability of the model are shown in Table 5.

According to the correlation coefficient $(R)$ and the coefficient of determination $\left(R^{2}\right)$, the data points have an adequate dispersion, but an adjusted coefficient of determination allows knowing the dispersion based on all of the independent variables (ER and SF) and not only based on one of them. On the other hand, the standard error of the estimate calculated means that the data has excellent accuracy, and Durbin-Watson number indicates that there is a positive autocorrelation for the analysis of regression $[0 ; 2]$. Further, the $\mathrm{CO}$ and $\mathrm{H}_{2}$ concentration in dry basis equations were calculated as functions of ER and SF as shown in Equations (7) and (8). Figure 9 shows the trend for $\mathrm{H}_{2}$ :

$$
\begin{aligned}
& C O=-8.071 S F-1.847 E R+34.369 \\
& H_{2}=26.036 S F+0.564 E R+15.074
\end{aligned}
$$

\section{Oxygen-Steam Blends vs. Air-Steam}

This section compares the results of this study to others carried out by the authors, using steam-air mixtures as an oxidizer and the same biomass (Bonilla and Gordillo, 2017). The use of oxygen-mixtures as gasifying agent enhances the temperature along the gasifier, and hence the mole fractions of $\mathrm{CO}$ and $\mathrm{H}_{2}$ in the syngas yield as compared to the use of steam-air-i.e., at $\mathrm{SF}=0.4$ and $\mathrm{ER}=3.2$, the $\mathrm{CO}$ and $\mathrm{H}_{2}$ dry basis concentrations were 25 and $27.5 \%$, respectively, for oxygen-steam, whereas these for gasification with air-steam were 12.4 and $12.4 \%$, respectively. More oxygen supplied implies more heat released by higher

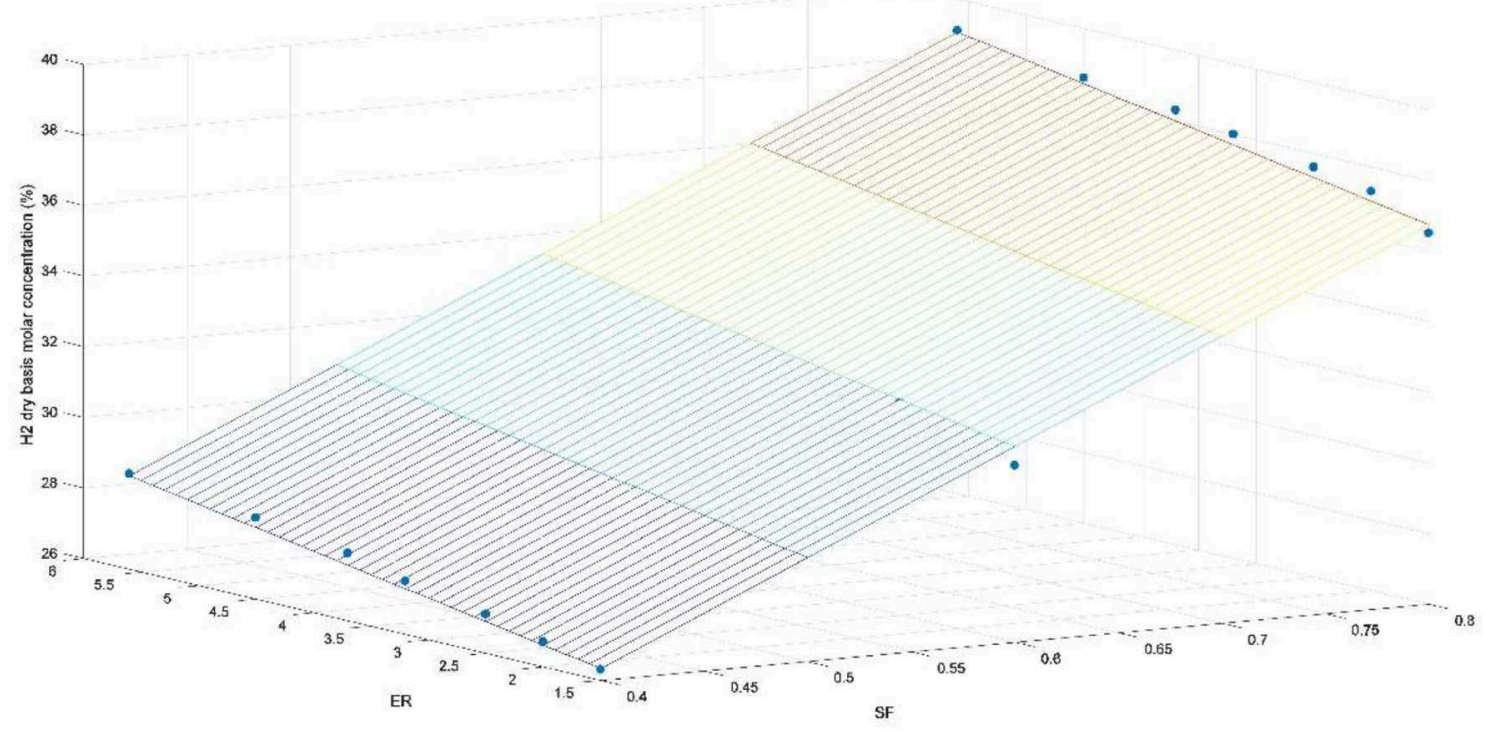

FIGURE 9 | Fitted plane as a function of ER and SF for dry $\mathrm{H}_{2}$ concentration.

\begin{tabular}{|c|c|c|c|c|c|c|c|}
\hline \multirow[t]{2}{*}{ SF } & \multicolumn{7}{|c|}{ ER } \\
\hline & 1.6 & 2.0 & 2.5 & 3.2 & 3.7 & 4.5 & 5.6 \\
\hline 0.4 & 4.61 & 4.44 & 4.42 & 4.65 & 4.41 & 5.40 & 6.53 \\
\hline 0.6 & 3.88 & 3.88 & 3.47 & 3.59 & 3.67 & 4.17 & 4.69 \\
\hline 0.8 & 2.57 & 2.62 & 2.77 & 2.72 & 2.72 & 3.03 & 3.58 \\
\hline
\end{tabular}

TABLE 6 | TEIR is the energy recovery ratio between oxygen-steam and air-steam gasification. 
char oxidation (more production of $\mathrm{CO}_{2}$ ). Also, when the air is supplied as oxidizer, a fraction of the heat released by the oxidation of char is consumed as sensible heat of the $\mathrm{N}_{2}$. Also, using oxygen instead of air increases both the HHV and CGE $\mathrm{NET}_{\text {, }}$ respectively i.e., at $\mathrm{SF}=0.6$ and $\mathrm{ER}=3.7$, the $\mathrm{HHV}$ and $\mathrm{CGE}_{\mathrm{NET}}$ were $8,283 \mathrm{~kJ} / \mathrm{SATP} \mathrm{m}^{3}$ and 0.61 by using oxygen, whereas the $\mathrm{HHV}$ and CGE $\mathrm{NET}_{\text {were }} 4,391 \mathrm{~kJ} / \mathrm{SATP} \mathrm{m}^{3}$ and 0.32 , respectively, for air-steam gasification. In general, the comparison of results shows that the use of oxygen instead of air improves syngas quality. Table 6 shows a ratio, defined by Equation (9), that gives information about the total energy recovered in the syngas produced for each mass unit of $\mathrm{CH}$ gasified, using oxygen-steam and air-steam gasification.

$$
T E I R=\frac{\left[H H V_{\text {syngas }} \cdot C G E_{\text {net }}\right]_{\text {Oxy }}}{\left[H H V_{\text {syngas }} \cdot C G E_{\text {net }}\right]_{\text {Air }}}
$$

Where, TEIR is the Total Energy Improvement Ratio, $H H V_{\text {syngas }}$ is the syngas Higher Heating Value and $C G E_{\text {net }}$ is the net Cold Gas Efficiency.

\section{CONCLUSIONS}

Results show that increased ER and SF ratios tend to decrease both the temperature in the combustion zone and the $\mathrm{CO}$ contained in syngas, whereas the $\mathrm{H}_{2}$ content in syngas increases as ER and SF increase. On the other hand, increased SF and decreased ER increase the production of $\mathrm{CO}_{2}$. The methane production was lower than $5 \%$ and increased as both ER and SF ratios increased. At constant ER, the $\mathrm{HHV}$ of syngas increases as when SF ratio is increased. The effect of the ER on HHV is to increase until ER $=3.2$, while at $\mathrm{ER}>3.2$ increasing

\section{REFERENCES}

Abbasi, T., and Abbasi, S. A. (2010). Biomass energy and the environmental impacts associated with its production and utilization. Renew. Sustain. Energy Rev. 14, 919-937. doi: 10.1016/j.rser.2009.11.006

Aslan, A. (2016). The causal relationship between biomass energy use and economic growth in the United States. Renew. Sustain. Energy Rev. 57, 362-366. doi: 10.1016/j.rser.2015.12.109

Bilgili, F., Koçak, E., Bulut, Ü., and Kuşkaya, S. (2017). Can biomass energy be an efficient policy tool for sustainable development? Renew. Sustain. Energy Rev. 71, 830-845. doi: 10.1016/j.rser.2016.12.109

Bonilla, J., and Gordillo, G. (2017). Adiabatic fixed-bed gasification of colombian coffee husk using air-steam blends for partial oxidation. J. Combust. 2017, 1-26. doi: $10.1155 / 2017 / 3576509$

Cerone, N., Zimbardi, F., Villone, A., Strjiugas, N., and Kiyikci, E. G. (2016). Gasification of wood and torrefied wood with air, oxygen, and steam in a fixed-bed pilot plant. Energy Fuels 30, 4034-4043. doi: 10.1021/acs.energyfuels.6b00126

Chen, X. (2016). Economic potential of biomass supply from crop residues in China. Appl. Energy. 166, 141-149. doi: 10.1016/j.apenergy.2016.01.034

Cutz, L., Haro, P., Santana, D., and Johnsson, F. (2016). Assessment of biomass energy sources and technologies: the case of Central America. Renew. Sustain. Energy Rev. 58, 1411-1431. doi: 10.1016/j.rser.2015.12.322

Gírio, F. M., Fonseca, C., Carvalheiro, F., Duarte, L. C., Marques, S., and BogelŁukasik, R. (2010). Hemicelluloses for fuel ethanol: a review. Bioresour. Technol. 101, 4775-4800. doi: 10.1016/j.biortech.2010.01.088
ER tends to decrease HHV. At constant SF, the $C G E_{\text {net }}$ always decreases as ER increases. The comparison between oxygensteam and air-steam gasification of $\mathrm{CH}$ shows that under the same operating conditions, the gasification with oxygen-steam increases the temperature along the gasifier, the $\mathrm{HHV}$ of the syngas, and the energy recovery. Additionally, the maximum cold energy recovery was $82 \%$ for oxygen-steam and $62 \%$ for air-steam gasification.

\section{DATA AVAILABILITY STATEMENT}

All datasets generated for this study are included in the article/Supplementary Material.

\section{AUTHOR CONTRIBUTIONS}

JB conceived and designed the analysis, collected the data, contributed data, performed the analysis, and wrote the paper. GG conceived and designed the analysis, collected the data, performed the analysis, and wrote the paper. CC collected the data, contributed data, and performed the analysis.

\section{ACKNOWLEDGMENTS}

The financial support from the internal financing grants of the Universidad de Los Andes is gratefully acknowledged.

\section{SUPPLEMENTARY MATERIAL}

The Supplementary Material for this article can be found online at: https://www.frontiersin.org/articles/10.3389/fenrg. 2019.00127/full\#supplementary-material

Gordillo, G., and Annamalai, K. (2010). Adiabatic fixed bed gasification of dairy biomass with air and steam. Fuel 89, 384-391. doi: 10.1016/j.fuel.2009. 07.018

Gordillo, G., and Rodriguez, C. (2011). Adiabatic gasification and pyrolysis of coffee husk using air-steam for partial oxidation. J. Combust. 2011:303168. doi: $10.1155 / 2011 / 303168$

Hernández, J. J., Aranda, G., Barba, J., and Mendoza, J. M. (2012). Effect of steam content in the air-steam flow on biomass entrained flow gasification. Fuel Process. Technol. 99, 43-55. doi: 10.1016/j.fuproc.2012.01.030

Hernandez, J. J., Lapuerta, M., and Monedero, E. (2016). Characterisation of residual char from biomass gasification: effect of the gasifier operating conditions. J. Clean. Prod. 138, 83-93. doi: 10.1016/j.jclepro.2016.05.120

Hussein, M. S., Burra, K. G., Amano, R. S., and Gupta, A. K. (2017). Effect of oxygen addition in steam gasification of chicken manure. Fuel 189, 428-435. doi: 10.1016/j.fuel.2016.11.005

International Energy Agency (2016). Colombia: Balances for 2010.

Joselin Herbert, G. M., and Unni Krishnan, A. (2016). Quantifying environmental performance of biomass energy. Renew. Sustain. Energy Rev. 59, 292-308. doi: 10.1016/j.rser.2015.12.254

Kirsanovs, V., Blumberga, D., Karklina, K., Veidenbergs, I., Rochas, C., Vigants, E., et al. (2017). Biomass gasification for district heating. Energy Procedia. 113, 217-223. doi: 10.1016/j.egypro.2017.04.057

Kurkela, E., Kurkela, M., and Hiltunen, I. (2016). Steam-oxygen gasification of forest residues and bark followed by hot gas filtration and catalytic reforming of tars: results of an extended time test. Fuel Process. Technol. 141, 148-158. doi: 10.1016/j.fuproc.2015.06.005 
Lenis, Y. A., Pérez, J. F., and Melgar, A. (2016). Fixed bed gasification of Jacaranda Copaia wood: effect of packing factor and oxygen enriched air. Ind. Crops Prod. 84, 166-175. doi: 10.1016/j.indcrop.2016.01.053

Li, H., Zhang, X., Liu, L., Wang, S., and Zhang, G. (2017). Proposal and research on a combined heating and power system integrating biomass partial gasification with ground source heat pump. Energy Convers. Manag. 145, 158-168. doi: 10.1016/j.enconman.2017.04.090

Liu, L., Huang, Y., Cao, J., Liu, C., Dong, L., Xu, L., et al. (2018). Experimental study of biomass gasification with oxygen-enriched air in fluidized bed gasifier. Sci. Tot. Environ. 626, 423-433. doi: 10.1016/j.scitotenv.2018.01.016

Pacioni, T. R., Soares, D., Di Domenico, M., Rosa, M. F. R., de Muniz Moreira, F. P., and José, H. J. (2016). Bio-syngas production from agroindustrial biomass residues by steam gasification. Waste Manag. 58, 221-229. doi: 10.1016/j.wasman.2016.08.021

Plis, P., and Wilk, R. K. (2011). Theoretical and experimental investigation of biomass gasification process in a fixed bed gasifier. Energy 36, 3838-3845. doi: 10.1016/j.energy.2010.08.039

Sandeep, K., and Dasappa, S. (2014). First and second law thermodynamic analysis of air and oxy-steam biomass gasification. Int. Hydrogen Energy J. 39, 19474-19484. doi: 10.1016/j.ijhydene.2014.09.134

Sansaniwal, S. K., Pal, K., Rosen, M. A., and Tyagi, S. K. (2017a). Recent advances in the development of biomass gasification technology: a comprehensive review. Renew. Sustain. Energy Rev. 72, 363-384. doi: 10.1016/j.rser.2017.01.038

Sansaniwal, S. K., Rosen, M. A., and Tyagi, S. K. (2017b). Global challenges in the sustainable development of biomass gasification: an overview. Renew. Sustain. Energy Rev. 80, 23-43. doi: 10.1016/j.rser.2017.05.215

Tanczuk, M., Junga, R., Werle, S., Chabinski, M., and Ziólkowski. (2017). Experimental analysis of the fixed bed gasification process of the mixtures of the chicken manure with biomass. Renew. Energy 136, 1055-1063. doi: 10.1016/j.renene.2017.05.074
Toklu, E. (2017). Biomass energy potential and utilization in Turkey. Renew. Energy. 107, 235-244. doi: 10.1016/j.renene.2017.02.008

Van Huynh, C., and Kong, S. C. (2013). Performance characteristics of a pilotscale biomass gasifier using oxygen-enriched air and steam. Fuel 103, 987-996. doi: 10.1016/j.fuel.2012.09.033

Wilson, L., John, G. R., Mhilu, C. F., Yang, W., and Blasiak, W. (2010). Coffee husks gasification using high temperature air/steam agent. Fuel Process. Technol. 91, 1330-1337. doi: 10.1016/j.fuproc.2010.05.003

Xiao, Y., Xu, S., Tursun, Y., Wang, C., and Wang, G. (2017). Catalytic steam gasification of lignite for hydrogen-rich gas production in a decoupled triple bed reaction system. Fuel 189, 57-65. doi: 10.1016/j.fuel.2016.10.078

Yang, Y., Brammer, J. G., Mahmood, A. S. N., and Hornung, A. (2014). Intermediate pyrolysis of biomass energy pellets for producing sustainable liquid, gaseous and solid fuels. Bioresour. Technol. 169, 794-799. doi: 10.1016/j.biortech.2014.07.044

Zhang, Z., and Pang, S. (2017). Experimental investigation of biomass devolatilization in steam gasification in a dual fluidised bed gasifier. Fuel 188, 628-635. doi: 10.1016/j.fuel.2016.10.074

Conflict of Interest: The authors declare that the research was conducted in the absence of any commercial or financial relationships that could be construed as a potential conflict of interest.

Copyright (c) 2019 Bonilla, Gordillo and Cantor. This is an open-access article distributed under the terms of the Creative Commons Attribution License (CC BY). The use, distribution or reproduction in other forums is permitted, provided the original author(s) and the copyright owner(s) are credited and that the original publication in this journal is cited, in accordance with accepted academic practice. No use, distribution or reproduction is permitted which does not comply with these terms. 